\title{
緊急腹腔鏡下手術前に診断しえた卵管捻転の1例
}

日本赤十字社 前橋赤十字病院 ${ }^{1)}$ 、辻仲病院柏の葉 ${ }^{2)}$

平石 光 ${ }^{1)}$ 、曽田雅之 ${ }^{1)}$ 、塚越規子 ${ }^{1)}$ 、大澤 稔1)、山田清彦 ${ }^{2)}$

\section{Clinical Findings and Images of Preoperatively Diagnosed Fallopian Tube Torsion}

\author{
Hikaru Hiraishi ${ }^{1}$, Masayuki Soda ${ }^{1)}$, Noriko Tsukagoshi ${ }^{1)}$, Minoru Ohsawa ${ }^{1)}$, Kiyohiko Yamada ${ }^{2)}$ \\ Japanese Red Cross Maebashi Hospital ${ }^{1}$, \\ Tsujinaka Hospital Kashiwanoha ${ }^{2)}$
}

\begin{abstract}
We experienced a case of Fallopian tube torsion that was diagnosed preoperatively. A 47-year-old nulligravida presented at the emergency department of Maebashi Red Cross Hospital with the chief complaint of sudden onset of severe lower abdominal pain just after defecation. On physical examination, severe tenderness and rebound pain in the right adnexa were noted. Computed tomography (CT) showed multilocular images in both adnexa, and magnetic resonance imaging (MRI) suggested bilateral hydro- or hemato- salpinges. Neither pentazocine nor nonsteroidal antiinflammatory drugs (NSAIDs) relieved her pain. Emergency laparoscopy revealed torsion and convolution of the right Fallopian tube, a left hydrosalpinx, and perihepatic fibrous adhesions. A bilateral salpingectomy was performed. Her postoperative course was uneventful. Pathological examination revealed hemorrhage, severe edema, and partial degeneration of the right Fallopian tube consistent with torsion of the right Fallopian tube; no evidence of malignancy was present. A preoperative test for chlamydial antigen in the cervix was negative. However, serum antibodies for chlamydia trachomatis showed a positive result for IgG and a negative result for IgA; thus suggesting previous existence of chlamydial pelvic peritonitis. The clinical features and images led to the correct preoperative diagnosis, and led to a prompt decision to perform emergency laparoscopic surgery. Fallopian tube torsion, although uncommon, should be included in the differential diagnoses of acute lower abdominal pain in women.
\end{abstract}

Key words: tubal torsion, hydrosalpinx, laparoscopy, CT, MRI

\section{はじめに}

卵管捻転は稀な疾患であるが、女性の急性腹症 の鑑別疾患として考慮ず゙きである。卵巣のう腫 茎捻転や子宮内膜症性囊胞の破裂の方が頻度とし ては多く、卵管捻転が術前に診断された報告はほ とんどない。今回、術前の診察およびMRIから卵 管捻転を診断し、腹腔鏡下に卵管切除を行い治癒 した 1 例を経験したので報告する。

\section{症例}

症例：47歳女性、未経妊未経産。身長 $162 \mathrm{~cm}$ 、体 重85kg、BMI 32.4、月経周期は不順であった。
主訴 : 排便後の急激な下腹部痛。

既往歴、家族歴：性交歴あり。クラミジアトラコ マティス感染治療歴あり。

現病歴：当日朝11時ごろ起床、排便後に急激な腹 痛を認め、13時30分頃に自家用車で当院救急科を 受診した。CT上、両側付属器に多房性の腫大を 認めた（図 1 )。付属器腫瘍捻転の疑いで救急科 から当科へ紹介となった。15時頃に婦人科診察を 行い、経腟超音波検査でひだ状構造と少量の debrisを伴う蛇行した右卵管腫大（図2）および 同部位の圧痛、隣接する卵巣様超音波像、反跳痛 を認めた。右卵管捻転あるいは右卵巣のう腫茎捻 転を疑った。妊娠反応は陰性であった。左付属器 
は圧痛を認めなかった。

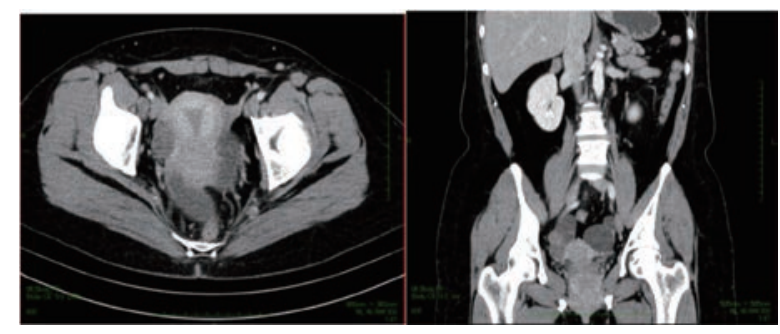

図 1 救急外来受診時CT：両側付属器に多房性腫痹を認めた。

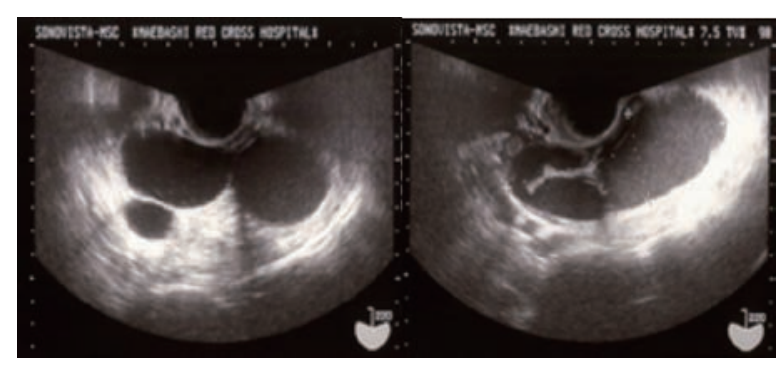

図2 経窑超音波検查: 右卵管腫大および同部位の土痛を認めた。

血液検查所見では、白血球増多 $(\mathrm{WBC} 11000 / \mu \mathrm{l})$ の他に著変を認めず、CRP $0.20 \mathrm{mg} / \mathrm{dl} 、 \mathrm{CEA}$ 1.3ng/ml、CA19-9 $5 \mathrm{U} / \mathrm{ml} 、 \mathrm{CA} 125 \quad 13 \mathrm{U} / \mathrm{ml}$ 、 後に判明した検査結果において、子宮頸管クラミ ジア抗原は除性、血清抗クラミジアトラコマティ ス抗体はIgG陽性、IgA陰性であり、腟分泌物細 菌培養検査にてStreptococcus agalactiae $(1+)$ 、 Streptococcus milleri group $(1+)$ 、 Lactobacillus sp. $(3+)$ を認めた。

強い下腹痛に対して、ペンタゾシン静注および フルルビプロフェンアキセチル点滴静注したが疼 痛は全く改善しなかった。CT画像で虫垂炎の所 見なく、悪性腫瘍鑑別のためのMRIが撮像可能で あったため施行、その結果両側卵管留水腫または 留血腫の診断を得た（図 3 )。右卵管は壁に粘膜 ひだ様の構造を認め、内部に出血を伴う捻れた卵 管水腫が疑われる像が認められ、さらに正常な右 卵巣が同定可能であった。左卵管水腫も認めたが、 捻転を疑わせる部分や出血像を認めず、正常な左 卵巣が同定できた。明らかな腹水貯留は認めなか った。

右卵管水腫の捻転の疑いで、本人および家族に 緊急腹腔鏡下手術の方針を伝え、卵管水腫が明ら かな場合には卵管切除術を行うことの説明を行 い、手術に同意を得た。

臍下端からオプティカル法で $5 \mathrm{~mm}$ トロカーを 㨂入し、左右下腹部に $5 \mathrm{~mm}$ トロカーを挿入する 3 孔式で腹腔鏡下手術を行った。子宮マニピュレ
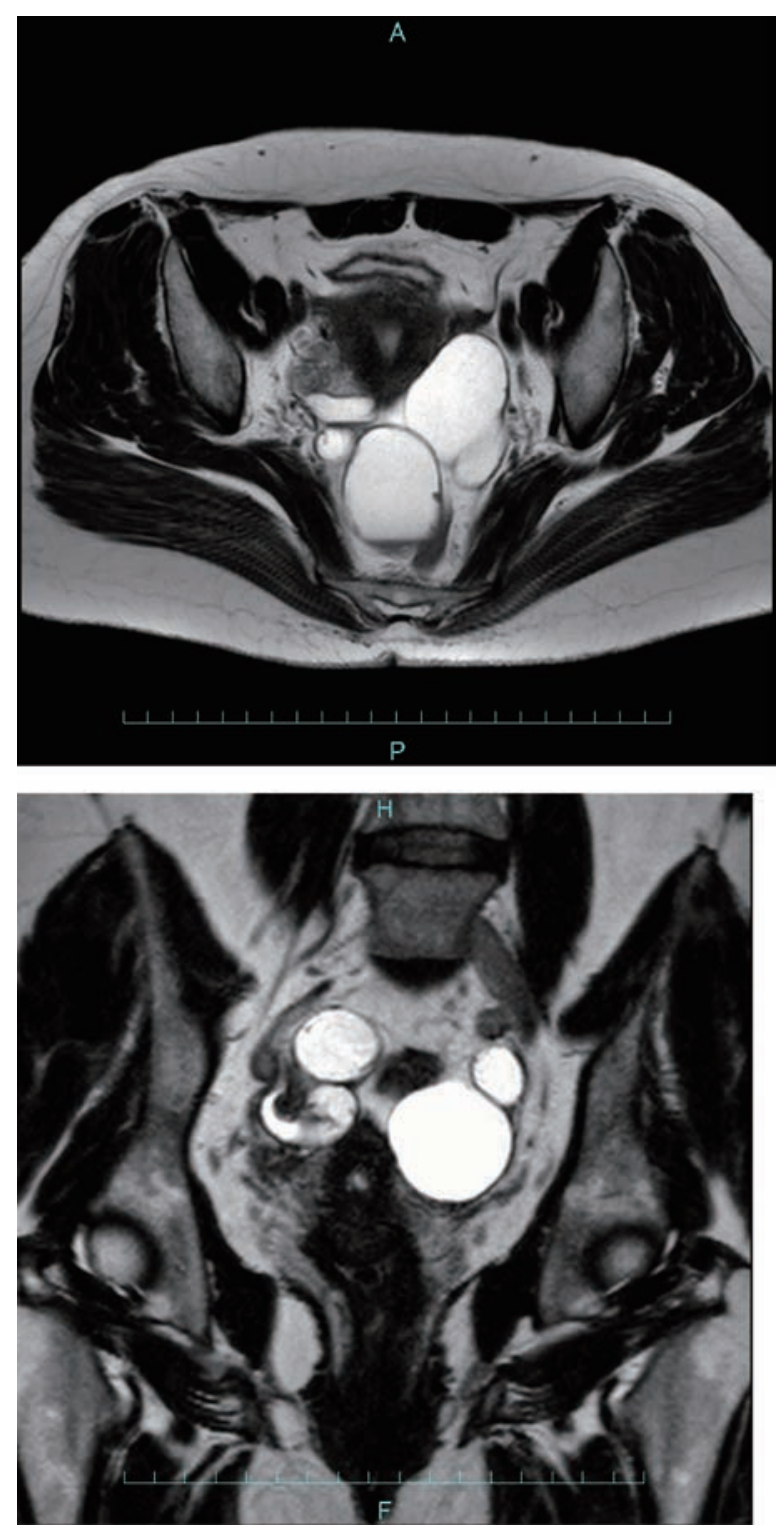

図3 術前MRI（T2強調画像、水平断と前額断、造影なし）：左卵管 水腫および右卵管血腫捻転の疑い。左右の正常卵巣が同定さ れ、右卵管の出血像を認めた。

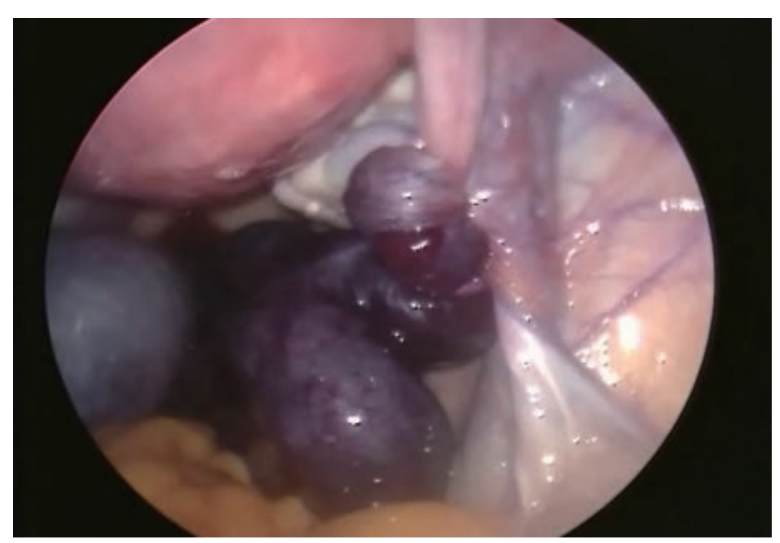

図4 腹腔鏡下術中所見 : 右卵管の捻転および壊死性変化を認めた。

ータ (八光) を使用した。腹腔内は右卵管捻転 (反 時計回りに 3 回転半、図 4) および左卵管留水腫 
の所見であった（図 5 )。左卵巣周囲に軽度の膜 性の癒着を認めたが、他に骨盤内に癒着は認めな かった。また、肝臟と周囲との癒着を認めた。バ イポーラカッティングフォーセプス (GYRUS) およびハーモニック ACE（エチコンエンドサー ジェリー）を使用し、卵巣機能温存を意識して卵 管間膜を卵管寄りに焼灼・切開し、腹腔鏡下に両 側卵管を切除し手術終了した（図 6 )。手術時間 は42分、術中出血量は少量であった。

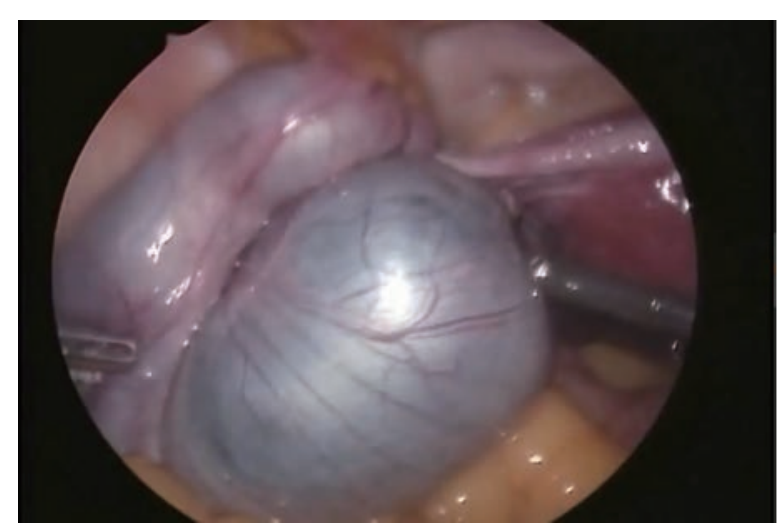

図 5 腹腔鏡下術中所見 : 左卵管水腫を認めた。

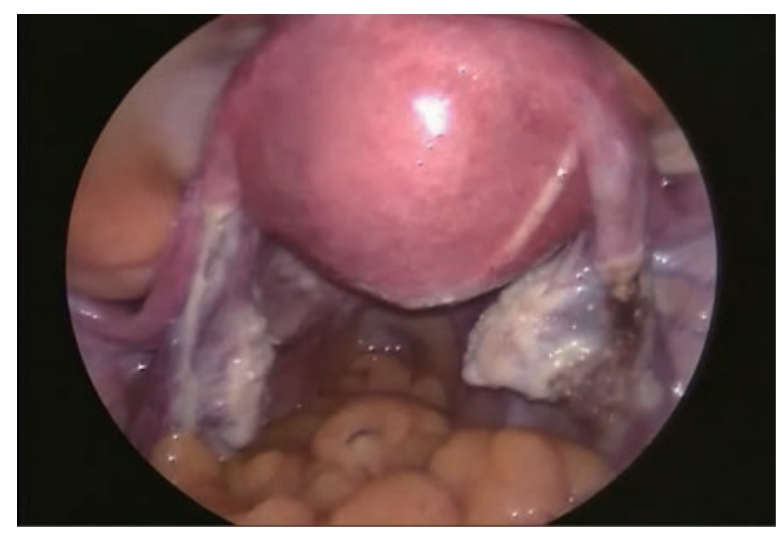

図 6 腹腔鏡下術中所見 : 両側卵管切除後。

腫大した右卵管内は暗赤色の血液に満たされて おり、病理組織診断では、卵管に高度の出血を伴 い、卵管捻転に一致する所見であり、捻転の原因 となる卵管原発腫瘍などを認めなかった。左卵管 は内腔が高度に拡張したものの炎症性変化は明ら かではなかった。術後経過は良好であり、術後3 日目に退院した。

救急外来受診時に提出した子宮頸管粘液クラミ ジアPCRは陰性であったが、クラミジアトラコマ ティス抗体は $\operatorname{IgG}$ 陽性、IgA陰性であり、クラミ ジア治療歴もあり、腹腔鏡下に肝周囲の癒着も存 在し、骨盤腹膜炎の既往が考えられた。

\section{考察}

卵管捻転は、1890年にBland-Suttonによって初 めて報告された ${ }^{1)}$ 。Hansenらによると発症頻度は 150 万人に 1 例程度と、極めて稀であることが報 告されている2）。一方で当院に打ける2012年 4 月 1 日から 2014 年 3 月 31 日までの婦人科急性腹症の 緊急手術141例のうち、卵管捻転は 1 例、卵巣の う腫茎捻転は13例であった。この期間では卵管捻 転は婦人科急性腹症の緊急手術の $0.71 \%$ 占める ことになり、極めて稀な疾患とは言いがたい。内 診㧍よび超音波検查やMRI、臨床所見から本疾患 を鑑別疾患として考える必要がある。

発症年齢は初経前の女児が約 $20 \%$ て1 13歳から 49 歳の生殖年齢婦人が約 $80 \%$ であり、妊娠中の発 症は $12 \%$ 程度と報告されている ${ }^{3)}$ 。最年少では 3 歳 7 か月児の報告 ${ }^{4)} や 、 4$ 歳児で、嘔気嘔吐を伴 う急性腹症で受診し、卵管捻転を解除することに より卵管温存可能であった例もある ${ }^{5)}$ 。このよう に月経発来前の症例も多数報告されており、国内 では最年少では 9 歳の症例報告6.7)、11歳の報告も ある ${ }^{8.9)}$ 。小児科との連携が必要となる。

術式は、卵管切除を基本術式とするが、アプロ 一チの方法は他の付属器腫瘍に準じて検討されう る。すなわち、過去の報告のレビュー、RCTな どによると、入院期間短縮、術後の発熱や疼痛の 軽減、合併症の予防という観点から、開腹手術よ り腹腔鏡手術が有利であると考えられた ${ }^{10,11}$ 。

骨盤腹膜炎から卵管水腫を来たして捻転に至る のではないかと考えうるが、若年女児での卵管捻 転の症例が多く存在することから考えると、性交 渉あるいは性感染症（クラミジアトラコマティス 感染など）がなくとも捻転は成立しうるものであ ることを念頭に置く必要がある。特に女児では、 腹痛が右下腹部にみられた場合には急性虫垂炎と の鑑別が難しい場合も想定される。

広く卵管間膜により固定されているが捻転の機 序に関しては、Antoniouらは、卵管自体に原因 があるもの（卵管留水腫掞よび留血腫、卵管腫瘍、 卵管手術既往、卵管の形態異常）と、卵管外に原 因があるもの（卵巣腫瘍や傍卵巣のう腫、骨盤内 癒着、骨盤内感染、妊娠）とに分類して考察して いる ${ }^{12)}$ 。本症例では、捻転に卵巣が含まれていな かった。骨盤内感染の既往に伴う卵管留水腫また は留血腫により捻転が生じた可能性が高い。ここ で、排便をきっかけに症状が発生した、というこ とについて推論を進めてみると、腹腔内圧の上昇 
や腸蠕動運動などが右卵管を捻転させる何らかの 誘因となったのではないかということが考えられ る。

左右の卵管捻転の発症頻度に関しては、7 対 3 で右側に多い。左骨盤腔は直腸が存在するため、 右骨盤腔よりも狭い。また、S 状結腸よりも回盲 部で蠕動運動が強いため、付属器もその影響を受 けやすいことが考えられる ${ }^{13,14)}$ 。本症例では、左 は卵管留水腫の状態であったが、右側だけが捻転 していた。右側に多いことと一致しており、しか も排便後の突然発症であり腸蠕動運動との関連が 示唆された。左側も放置すれば後々捻転した可能 性もある。

若年者の場合には、卵管水腫がなぜ起きるのか を解明することは困難を伴うものと予想される が、感染症以外にも先天的な形成異常の可能性や、 傍卵巣のう腫による卵管捻転の可能性があ $3^{15,16)}$ 。また、生殖年齢の卵管捻転では、妊娠中 の症例も報告されている ${ }^{17.18)}$ 。稀なものでは妊娠 中の卵管筋腫の捻転症例の報告がある ${ }^{19)}$ 。卵管の うっ血が起こりやすい排卵期から月経期に起こり やすいと報告されているが、本症例では不順な周 期であり、月経周期との関連は不明であった。ま た、類似する疾患としては、稀な異所性妊娠であ る卵巣妊娠で捻転した症例も報告されている ${ }^{20)}$ 。 不妊手術である卵管結紮後の卵管捻転症例も報告 されている ${ }^{21)}$ 。閉経後の症例報告はさらに少ない。 しかし70歳の報告もあり ${ }^{22)}$ 、高龃であっても起こ りうる疾患である。

卵管捻転は、本症例のような水腫に伴う報告が 多いものの、卵管の腫瘍が原因と考えられる捻転 の症例報告も少なくない。卵管子宮内膜症に起因 した卵管捻転の症例 ${ }^{23)}$ や、卵管の奇形腫に伴う もの ${ }^{24)}$ 、卵管癌の捻転症例 ${ }^{25-27)}$ 、卵管の筋腫に伴 う捻転症例 ${ }^{28)}$ が挙げられる。捻転の原因となり うる腫瘍の存在により、稀ではあるが卵管捻転を きたす症例があるとされている。

本症例では卵管捻転を術前から疑ったことによ り、年齢を考慮して卵管切除のみを行うことを説 明し、さらにもし卵巣のう腫の茥捻転であれば、 卵巣のう腫の核出、あるいは付属器摘出を行うこ とを本人と家族に術前に説明して緊急手術を行う ことができた。本症例では実際には、挙児希望の ない47歳経産婦の卵管捻転症例であり、患側の卵 管留血腫だけではなく反対側の卵管留水腫も認め たことから根治性を考慮して両側卵管切除を行っ た。正常卵巣は温存可能であり、術後の更年期症
状も認めず、術後も術前同様に周期的に月経を認 めた。

救急外来で初診時に速やかに手術を決定し、緊 急腹腔鏡下手術を行ったため、卵管捻転による疼 痛を感じる期間も短く済んだと思われた。家族へ の術前説明待ちの時間を要したが、当院受診から 手術開始まで約 5 時間であった。

卵管捻転の術前診断には超音波検查とMRIが有 用な可能性がある ${ }^{29)}$ 。術前の画像診断では超音波 画像で囊胞内にdebrisを認めると報告されてい $る^{30}$ 。本症例では粘膜ひだ状の隆起を伴う屈曲し たのう胞性病変を認めており、卵管腫大が疑われ る所見であり、傍らに正常卵巣が同定できた。 CT扔よび超音波検査・内診だけでは卵管以外の 捻転の可能性も除外できないが、MRIで右卵管に のみ捻転による水腫や出血像を認め、正常卵巣も 同定されたことにより、術前の卵管捻転を強く疑 うことができた。MRIを術前に行うことに長い時 間を要するのであれば、卵巣および卵管の両方の 場合の説明を行い、手術を速やかに開始すること も妥当であると思われる。本症例では、家族を待 って手術の説明をするまでの間にMRIを施行する 時間的な余裕があった。MRIを行う前に造影CT を行った場合には、単純撮影でも捻転の診断がつ く可能性はあるが、悪性所見の否定のためには、 造影MRIを施行することが望ましい。すなわち、 時間的な余裕があれば、卵巣癌や卵管癌、子宮体 癌を否定する目的で造影MRIを行うことも有益で あると思われる。術前に卵管捻転の診断が可能で あれば、年齢によっては術後の妊娠方法に関する 相談がしやすく、卵管切除した場合の本人・家族 の今後のIVF希望等も確認できる可能性があり、 場合によっては卵管の温存を含めてょり希望に添 った手術を選択できるかもしれない。全ての付属 器捻転症例に術前MRIを行うことは現実的ではな い。しかし、超音波検查で多房性のう胞とは別に 同側の正常卵巣が確認された場合には、卵管捻転 を疑ってCTよりもMRIを選択することで、術前 診断が行いやすくなると考えられる。また、MRsalpingo-graphyが有用であったという報告もあ る ${ }^{31}$ 。緊急手術に踏み切る前に、より確実な術前 診断を必要とする場合には、有効な手段かもしれ ない。

卵管捻転の根治的術式は卵管切除であるが、若 年症例で卵管の壊死所見がない場合には、卵管捻 転の解除のみを行い卵管を温存したという報告も ある。しかしBoukaidiによると10歳代の卵管捻転 
症例に捻転解除を行った 4 人中 3 人は再発をきた しており ${ }^{32)}$ 、卵管を温存した場合には再発のリス クがあることを念頭におかなければならない。挙 児希望の強い場合でも、体外受精肧移植（IVFET）という選択肢があり、卵管切除は卵巣機能 には影響を与えないということが報告されてい る33)。また、体外受精を前提とした卵管留水腫を 有する不妊患者に対して腹腔鏡下卵管摘出術は有 用であり推奨されている ${ }^{34)}$ 。したがって、腫大卵 管を温存することには慎重な対応が必要である。

\section{結語}

術前に診断し得た卵管捻転の症例を経験した。 臨床所見、内診、および超音波検查やMRI等の画 像診断所見から卵管捻転が強く疑われ、緊急腹腔 鏡下手術を行い治癒した。MRIでは正常卵巣の同 定および出血を伴う卵管捻転の所見が認められ た。付属器の腫大を伴った同部位の突然の下腹部 痛患者を診た場合、ともすれば卵巣のう腫の茎捻 転や子宮内膜症囊胞の破綻等、頻度の高い疾患を 想定することが多いと思われる。一方で、患者家 族に時間をかけた説明を行うことがやや困難な緊 急の状況においては、実際にどのような手術を行 うのか、術後の状況がその後にどのように影響す るのか、ということを想定しておくことがきわめ て重要と思われる。その意味において、婦人科的 急性腹症に扔いては、卵管捻転の可能性も常に考 慮して対応していくことが望ましいものと考えら れ、本疾患を念頭に術前にMRIを行うことも考慮 されると考えられた。

本論文の要旨は第53回日本産科婦人科内視鏡学会 学術講演会において発表した。

利益相反について

今回の論文に関連して、開示すべき利益相反状 態はありません。

\section{文献}

1) Bland-Sutton T. Salpingitis and some of its effects. Lancet. 1890; 2: 1146.

2 ) Hansen $\mathrm{OH}$. Isolated torsion of the fallopian tube. Acta Obstet Gynecol Scand. 1970; 49: 3-6.

3 ) Regad et al. : Etude anatomo-pathologique de la torsion des trampets uterines Gynecol Obster. 1933; 27: 519-535

4) Neel HB, et al: Torsion of the normal fallopian tube.
Obstet Gynecol 1972; 39: 80

5 ) Kurzbart E, et al. : Isolated torsion of the fallopian tube in premenarcheal girls. J Pediatr Surg. 1994; 29 (10) : 1384-5.

6 ) 北原修一郎：小児卵管捻転の 1 例. 日本小児外科学 会雑誌 $2006 ； 42(1) ： 118$

7 ) 江口尋 : 卵管留血腫を伴った茎捻転の 9 歳の 1 女児 例. 日本小児外科学会雑誌 $2002 ; 106 （ 9): 1323$

8 ) Markhardt BK, et al: Isolated torsion of the fallopian tube in a menarchal 11-year-old girl. Pediatr Emerg Care. 2008 Jun; 24 (6) : 374-6

9 ）権丈洋徳、他：11歳の若年者に発症した卵管留水腫 捻転の 1 例. 日産婦内視鏡学会. $2010 ; 26 （ 2)$ : $453-6$

10) Medeiros LR, et al: Laparoscopy versus laparoscopy for benign ovarian tumour. Cochrane Database Syst Rev. 2009; CD004751

11) Yuen PM, et al: A randomized prospective study of laparoscopy and laparotomy in the management of benign ovarian masses. Am J Obstet Gynecol. 1997; 177: $109-14$

12) Antoniou N, Varras M, Akrivis C: Isolated torsion of the fallopian tube: a case report and review of the literature Clin Exp Obstet Gynecol. 2004; 31 (3) : 235-8.

13) Provost MW. Torsion of the normal fallopian tube. Obstet and gynecol. 1972; 39 (1) : 80-2.

14）加藤純爾：卵管溜水腫茎捻転の 2 例. 産婦人科の世 界 $1979 ; 51: 1065-1071$

15）橋口和生：傍卵巣囊腫に伴う卵管捻転の 1 例. 日産 婦東京会誌. $1992 ； 41 （ 2 ）: 129-132$

16）英久仁子：小さな傍卵巣囊腫を伴う卵管捻転の一症 例. 日産婦内視鏡学会. $2014 ; 29(2): 475-477$

17) Simsek $Y$, et al: Hydronephrosis of pregnancy associated with torsion of the fallopian tube: a case report. Eur Rev Med Pharmacol Sci. 2011 Apr; 15 (4) : 448-51.

18) Shirokane M, et al: Isolated torsion of a left normal fallopian tube during pregnancy. J Nippon Med Sch. 2011; 78 (1) : 40-1.

19) Uchida K,et al: Tubular myoma with torsion in pregnancy: a case report. Sanfujinka No Jissai. 1970 Nov; 19 (11) : 1177-9.

20) Pan HS, et al: Ovarian pregnancy torsion. Arch Gynecol Obstet. 2004 Sep; 270 (2) : 119-21.

21) Ikeda $S$, et al: Torsion of the fallopian tube following sterilization. Gynecol Obstet Invest. 1998; 46 (4) : 271-3.

22) Ding DC, et al: Isolated torsion of the hydrosalpinx in a postmenopausal woman. JSLS. 2007 Apr-Jun; 11 (2) : 252-4.

23) Peng T, et al: Endometriosis and perimenarchal tubal torsion. A case report. J Reprod Med. 1989 Nov;34(11):934-6. 
24) Tuchel V, et al: Fallopian-tube teratoma with torsion of the pedicle. Zentralbl Gynakol. 1963 Jun 22; 85: 889-93.

25) Azodi M, et al: Primary fallopian tube carcinoma with isolated torsion of involved tube. Eur J Gynaecol Oncol. 2000; 21 (4) : 364-7.

26) Sanyal R, et al: Primary carcinoma of the fallopian tube with torsion. J Indian Med Assoc. 1989 Jun; 87 (6) : 145-6.

27) Truskett ID, et al: Adenocarcinoma of fallopian tube with torsion. N Y State J Med. 1968 Dec 1; 68 (23) : 3062-5.

28) Misao $\mathrm{R}$, et al: Leiomyoma of the fallopian tube. Gynecol Obstet Invest. 2000; 49 (4) : 279-80.

29) Chene G, et al: Surgical implications of the potential new tubal pathway for ovarian carcinogenesis. Journal of minimally invasive gynecology. 2013; 20 (2) : 153-9.

30) Clare J, et al. : Risk-reducing salpingectomy in Canada: a survey of obstetrician-gynaecologists. Obstet Gynaecol Can. 2013 Jul; 35 (7) : 627-34.

31) ACOG Practice Bulletin No. 89 elective and riskreducing salpingo-oophorectomy.

32) Orazi C, Inserra A, Lucchetti MC, et al. Isolated tubal torsion: a rare cause of pelvic pain at menarche. Sonographic and MR findings. Pediatr Radiol. 2006; 36: 1316-8

33) Sherer DM, et al: Endovaginal sonographic features associated with isolated torsion of the fallopian tube. J Ultrasound Med. 1991; 10 (2) : 107-9.

34）加藤裕之、他：卵管留水症における MR-salpingographyの有用性について. 日産婦内視鏡学会. $2009 ; 25$ ( 2 ) : 452-455 